\title{
Microfinance Institutions: It's Role in Palestine Economic Development
}

\author{
Sharif M. Abu Karsh ${ }^{1}$, Anan Y. Deek ${ }^{2}$ \\ ${ }^{1}$ Department of Banking and Financial sciences, Faculty of Administrative and Financial sciences, Arab \\ American University, P.O. BOX 240, Jenin - West Bank, Palestine \\ ${ }^{2}$ Faculty of Graduate Studies, Arab American University, P.O. BOX 240, Jenin - West Bank, Palestine \\ Correspondence: Sharif M. Abu Karsh, Department of Banking and Financial sciences, Faculty of \\ Administrative and Financial sciences, Arab American University, P.O. BOX 240, Jenin - West Bank, Palestine.
}

Received: December 19, 2018

Accepted: January 11, 2019

Online Published: January 21, 2019

doi:10.5539/ibr.v12n2p165

URL: https://doi.org/10.5539/ibr.v12n2p165

\begin{abstract}
Microfinance is a tool for state poverty reduction and addition in number of these institutions are the support solution which brings overall improvement in the reconciliations. The current research study investigates the impact of these MFIs towards the development of economic condition of the state. The current study aims to explore more about MFIs, economic development with the support of past counts, as well the direct and indirect benefits associated with the MFIs. Data was collected from primary and secondary sources (Mixed strategy) for creating the more rigor and objectivity under working the positivist paradigmatic approach. This study highlights the major economic problem exists in Palestine is related to poverty. Additionally, micro financing is the term associated for the development of these barriers that impacts as a hindrance for any of the economy growth level. The results of the study show that the small level micro-financing is the best resource for the economic stability as well development.
\end{abstract}

Keywords: MFIs, banking, microfinance, economic structure, Palestine

\section{Introduction}

Microfinance is often reflected as a dual instrument or a tool for fighting against poverty in developing states and for the reconciliation of the post conflicts. Numerous economies had labored and shaped the settings for microfinance. After 1990 microfinance got more importance a source of funding (resource) and added more the investment for the reduction of poverty. The term of microfinance was in existence in 70's moreover it gained a standing position after 2006 when Grameen and Yunus bank collected the Noble prize on behalf of their struggles for the creation of the social and economic level of the country. Through this intercontinental outline a tool for the poverty improvement was protected, on the other side, few states with post-conflict have combined the microfinance with their reformation strategies. Realism in this regards presented that within few decades, microfinance has been combined or as well incorporated among the reformation and development strategies of the countries (post-conflict) having an aim to be more than they expect (Nagarajan et al., 2004).

Kosovo (1999) after war bring into being itself in the shocking situation that the whole economy shrank in results the banking arrangements have been ruined. The requirement for the financial sources has also increased than before. So within this content, Kosovo applied the both methods of the microfinance for fighting against the poverty conditions of the state at that time. Furthermore, the focus was also to originate the new growth opportunities for private sector and small businesses. Kosovo microfinance segment forward-looking speedily initiated a microfinance project as a donor funding in 2000 and later on converting themselves towards the financially sustainable microcredit organizations (MCOs). Most of the defendant's view microfinance system of Kosovo's and as well the complete MFIs in Kosovo as a prosperous section. However, Bateman (2012) explored that few hesitate to stretch the optimistic attitude and assessment, by way of MCOs have been view as a success based organizations, reasonably the kind providing the funding to the needy (poor) people, that was the situation with post conflicted countries as the case of Kosovo.

Currently, MFIs are the valuable financial service but not considered as a useful source for the transformation of the economic and social involvement (Mossman, 2005). Chang (2012) explored that others, responding in 
contradiction of high potentials, discharge this microfinance field as a failure on the argument that to consider it as a neoliberal gadget that captivated that donors but they are failed to provide the services that support the poor societies. Moreover, the smooth understanding viewer concern with the arguments that "microfinance lost its moral scope" with the more concentration towards the productivity of the moneylenders rather than the poverty of the common men (Hulme et al., 2014). The idea behind the microfinance was upfront as providing the capital to the customers in results increased the earning of the debtor and moreover resulted in improving the poverty condition of the general public better.

This study examines the statements of microfinance as its effects towards the economic development of the Palestine state. This research discusses the active role of small microfinance institutions towards the rural and local progress of the Palestine economy. Furthermore, this study explores the overview of the dimensions of poverty in Palestine as well the inequalities that are dominated among the urban versus the rural areas of the Palestine nationals regarding the service they are provided added more the activities of microfinance institutions behind these initiatives. This study focused on a total of the eight small microfinance institutions of the Palestine that are currently operating their services as well as impacting the economic condition of Palestine.

MFIs supports the elementary financial services of the needy who are considered as a poor or having the income level low. MFIs are increasing their initiatives by focusing more on these activities and services to shortfall the categories of finance need by providing easy and attractive loan installment modes. Microfinance is considered instrumental in the upgrading the living of poor and enabling them to be the part of state development by concentrating on small loan schemes.

\section{Research Background}

Microfinance is parallel to the consumer finance gives a clear explanation that contributors (donors) and investors must diagnose that entrée to microfinance is not always kind (Karim, 2011). In the 1990s, the loan refund rate attached with an indication of stable demand needed to be used as rough impact signs. Schicks (2013) stated that if these funds are not resulting in the high rate of returns on investment then why customers come to purchase repeatedly. Fluidity needs somewhat drive these microfinance steeps and borrowing. It is cooler to understand that how these debt issues aimed to sustain the demand. Cull et al. (2017) stated that the effect of the microfinance could be seen in the perspectives of as well intervention that, in spite of the modest availability of average benefits there is a need to establish minimum cost-benefit ratios.

Sabri (1999) concluded in his research that in the Palestinian economy, the closure policies as well as the overpass points which obstruct the drive of goods and workforce. Lack of infrastructures, technology updatation as well as the raw material financial costs is also be concerned with the problems of Palestine's. Few of the related issues within the economy of Palestine also includes the entrepreneurial perspectives where they are running the accounts with the high-interest rate factors and the inflexibility level of credit financing due to the guarantees and warranties demanded by the banks.

This economy has passed through more than a few phases. It has been observed that the formation of Palestinian National Authority, this economy has detected the recovery in the economy, where the income level upgraded by $6 \%$ as well as unemployment rate also goes down to $3.5 \%$. Instead of this, the Palestine's economy has suffered through to operate due to the assistance they have collected from donor's side.

MFIs contribute indirectly and directly to economic growth. The direct contributions by creating the value for the small entrepreneurial business, positive spillovers and improvements in the primary human capital structure development like education, health, and nutrition. Ravallion (2001) stated that the direct benefits also include the decrease in poverty level and inequalities. Kia et al. (2009) scrutinized the 61 developing countries and presented the evidence that MFIs are more bends towards the cut down of income deficiencies as well inequalities openly by eliminating the credit restraints of the poor. Hardy et al. (2002) stated that there are numerous studies related to the examining the uneven contribution of micro creditors cross country.

On the other hand, the indirect contribution of MFIs towards the economic growth highlights that the development of the financial sectors of the economy through the better quality access towards the finance sources, a combination of the household financial necessities. Barr (2005) explained that few of the other reasons that MFIs enhance the market extending in results promotes the financial growth, MFIs is the most reliable instrument for well-functioning of the poorly developed states, MFIs improve the home country financial health by holding down the hindrances.

Honohan (2004) predicts that the financial sources are more strongly associated with low-income level respondents (moreover population) and added more as the national resource it is ignored for the stemming up of 
the resources. Furthermore, the finance sector advancement is not just to decrease the poverty level but also improves the financial structure of the country indirectly. The amount of the poor household's entré to numerous financial markets as well services that MFIs indorses might help to reduce the inequality or poverty.

\section{Objectives, Rational and Limitation of Research}

\subsection{Research Objectives}

The core objective of the current research study is to explore the impact of the microfinance (role of the banking sector) for the development of the Palestine's economy. Moreover, it will look into the situations of the banking sector for the direct economic development and MFIs role for indirect economic development benefits.

\subsection{Research Rationale}

Small Medium enterprises also play a vital role in economic development and enhancement. Instead of production of low rated products and services to the target group with the focus of to reduce unemployment by expanding the job opportunity networking. in the current perspective, the role of the banking sector within any economy influenced their impact towards the economic development strategies. Therefore, micro-financing enhances the economic conditions and made positive reflections which is the core focus of the current investigation. The economy that comes under the array of a developing economy and handling the financial crisis, the role of MFIs in this economy is appreciable as well needed.

\subsection{Research Limitations}

There are also few of the limitations that are concerned with this research study that might be the concern of the future directions for many of the researchers. The current data that has been taken for this research study was a combination of primary and secondary data. The discussion, as well as the findings, were interpreted on behalf of the available facts given but later on, this should be processed with the ratios analysis predicts the values comparisons of different banks in a clearer way that which contributing more towards the development of the economy overall.

\section{Research Questions}

From the above problem statement and in consideration of core objectives of research the following research questions have been formulated:

RQ1: How MFIs and the economic development of Palestine's economy is interrelated?

RQ2: What are the direct benefits of MFIsand the Palestine's economy?

RQ3: What are the indirect benefits associated with MFIs and the Palestine's economy?

In spite of the highly literate population, the Palestinian economy comprises $0.01 \%$ of world economy, and the Unemployment is dangerously high at $26.9 \%$. The Palestinian economy is dependent mainly on government spending \& Services, while the exports are minimal while the economy imports everything from abroad, thus, the growth is weak. Therefore, as it relates to Microfinance, the current state of the economy will be greatly enhanced by increasing investments in productive assets; i.e. industries, agriculture, tourism, IT. Palestine's penetration of microcredit to the total population stands at $2 \%$ ( $90 \mathrm{~K}$ clients of 4.5 million population). Currently, there are 8 Microfinance Institutions (MFIs) affiliated with the Palestinian Network for Small and Microfinance; ASALA, VITAS, REEF, UNRWA, PDF, ACAD, FATEN, Al-IBDAA. The (8) MFIs operate under various legal structures, such as non-governmental organizations (NGOs), co-operatives, non-profit companies, and donor programs. "Several studies, which were carried out in the Palestinian credit space, have uniformly agreed on the pre-existence of a significant gap between finance demand and supply in Palestine. A study by Federcasse and the PMA estimated this credit gap to be over $\$ 80$ million per year. ICON-INSTITUTE estimated the lending gap attributable to MSMEs in Palestine to be between US\$ 623 million - US\$ 668 million. This indicates a significant shortage of finance for Palestinian MSMEs and an immeasurable obstruction to the full development of the Palestinian economy."

The OPT since the beginning of the $19^{\text {th }}$ century featured interruptions with breakouts of violence and conflict. As such, the progress of the microfinance sector has been a story of resilience but cautious growth. The political situation worsened by the end of the 1990s and the early 2000s; first \& second Intifada, 2002 Israeli invasion of areas A in the West Bank and 3 consecutive wars on Gaza Strip.

In the Palestinian case interest in the study of the microcredit sector is also motivated by another specific reason. The Palestinian economy largely relies on foreign help, and MCIs are no exception. Reliance on external donations has major implications in terms of governance and performance, as donors are mainly motivated by 
political and ideological aims, while local managers have to balance these objectives with the consequences of operating in an unstable economic and political climate. Wide availability of donations is also itself part of the problem as it generates passive, if not parasitic, attitudes among debtors (Israel/Palestine Centre for Research and Information [IPCRI], 2005).

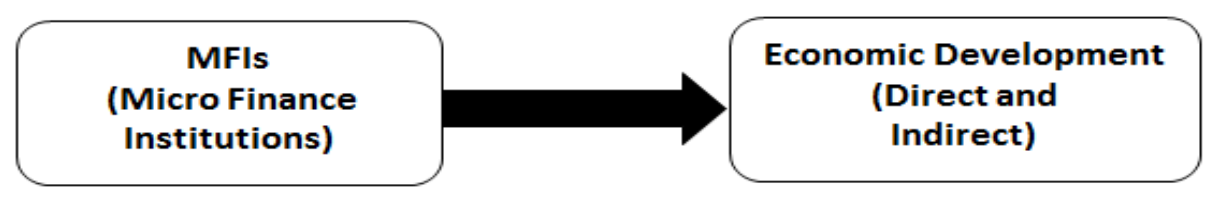

Figure 1. Conceptual Framework

Source: Self conceptualized on the base of Literature and secondary data of MFIs

\section{Research Methodology}

Research methodology is concerned with the path of action that the researcher is going to adopt for the current investigation. The whole philosophy revolves around three basic paradigms includes positivism, interpretivism, and critical research paradigm.

\subsection{Research Paradigm}

This research study is based on the positivist paradigm where the intentions of the individual are based upon phenomena of objectivity at its epistemological level, according to ontological level the reality is here, but the researcher is going to investigate the reality of the MFIs impact on the Palestine's economic development. In this context, it infers that MFIs development is interrelated with the economic growth. Both of these are the different drivers and are difficult to untie. For assessing the casualty, the investigator chooses the variables named dependent as well independent (Levine et al. 2000).

The research data has been collected from primary and secondary sources. For earlier histories or trend secondary source of data has been used. The economic review of Palestine, various Palestine's publications of microfinance has been used for the support of secondary data. This data has been supporting to evaluate that what has been done to conclude the current research.

\subsection{Population and Sample}

Currently, there are 8 Microfinance Institutions (MFIs) affiliated with the Palestinian Network for Small and Microfinance; ASALA, VITAS, REEF, UNRWA, PDF, ACAD, FATEN, Al-IBDAA. The eight MFIs operate under various legal structures, such as non-governmental organizations (NGOs), co-operatives, non-profit companies, and donor programs.

\subsection{Data Collection}

Therefore, according to the current research study objectives both sources have been observed for collecting views regarding poverty reduction. Primary data has been taken through the questionnaire with a measurement on the Likert scale. On the other hand, data on the development of financial institutes, secondary data has been used published in the economic survey reviews of the Palestine's state. For primary data collection regarding poverty has been taken from the beneficiaries of the concerned banking institutes. The questionnaire was based on the 18 items rely on the LIKERT scale to take the views of the beneficiaries of MFIs, e.g., the effect of MFIs on their livings standards, improvements as well social stability, etc.

\subsection{Instrumentation and Statistical Analysis}

Primary data collection instrument consists of 18 items which include (The small loans is the main foundation of income for family, the family touches that its income has enlarged after getting loan, the influence of the scheme is careful optimistic to the family, the scheme revenue chiefs to recover the family spending on food, etc.). The collected data has been scrutinized and analyzed on SPSS to conclude the findings of the current research data.

\section{Findings and Results}

The present study results indicated that $88 \%$ beneficiaries stated that the primary resource of their income is now attached with MFIs. 74\% got up their income level after they got grant ensured from the bank. $74 \%$ observed that this type of micro financing has a positive image towards them. The spending of families drives increase for the social requirements such as food, education, clothing etc. are increased that is responded by $80 \%$ of the beneficiaries. 
The concern of reducing poverty by increasing job opportunities by lowering unemployment families stated that their employed rate of family stands up by $82 \%$ with the increasing factor of employment-based projects. According to the beneficiary people they need regularly to last to invest chunks of the revenue of the arrangement to upsurge the wealth to achievement of creative assets or goods to let them to enlarge its actions to allow the scheme to constancy, and the poor economic circumstances practiced by the segment has had a negative influence on the revenue of most of these tasks. $80 \%$ of the respondent's states that they have the intention to further grow up and come up with their own project work that in results impact the economic growth level of the Palestine's state.

On the other side the Economic survey of Palestine (2016-17) gave a clear comparative picture of the poverty situation during past decades. Headcount ratio also explains that the population poverty situation has been changed from past decades with a little bit improvements by the contribution of the banking sector as well. Poverty reduction in headcounts as the slightest difference shows the direct improving in poverty with microfinance. The primary data about the banks have been collected from the different banks listed in the below tables. This comprises the complete profile including the number of staff members each of the banks has with the proportion of male as well female staff members. The number of branches enhancement as well showing the increasing trend of the role of banking related finance bundles.

Table 1. GDP wise growth of Palestine's economy

\begin{tabular}{llllllllll}
\hline & $\mathbf{2 0 0 8}$ & $\mathbf{2 0 0 9}$ & $\mathbf{2 0 1 0}$ & $\mathbf{2 0 1 1}$ & $\mathbf{2 0 1 2}$ & $\mathbf{2 0 1 3}$ & $\mathbf{2 0 1 4}$ & $\mathbf{2 0 1 5}$ & $\mathbf{2 0 1 6}$ \\
\hline GDP In US\$ Bn. & 4.88 & 5.24 & 5.75 & 6.42 & 6.8 & 6.9 & 7.5 & 7.7 & 8.0 \\
Population & 3.6 & 3.6 & 3.7 & 3.9 & 4 & 4.2 & 4.3 & 4.4 & 4.5 \\
GDP\$ /Capita & 1,395 & 1,455 & 1,555 & 1,646 & 1,700 & 1,685 & 1,744 & 1,750 & 1,777 \\
\hline
\end{tabular}

Table 2. Banks Profile

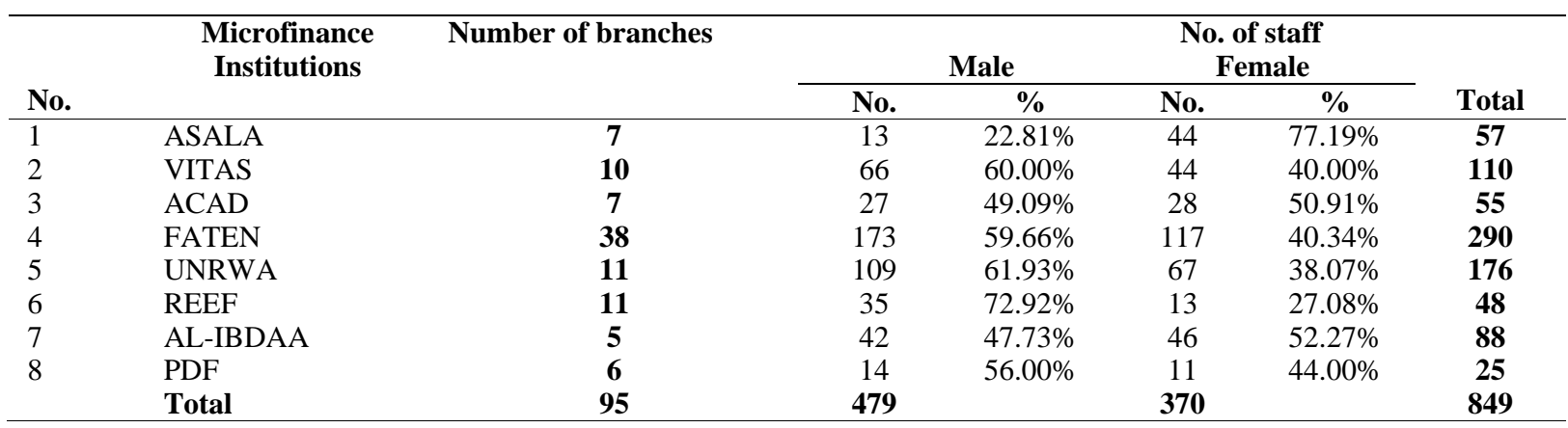

Source: Economic survey of financial institutes

The above Table 2 highlights the complete profile of the banks with respect to the increasing trend of the banks towards number of clients as well as number of active loan portfolios. UNRWA'S microfinance accomplishments focused is to delivered credit to small as well as medium scale businesses with an original capital funding of < USD 500,000. By way of the Microfinance Section evolved, its operations were long into the West Bank in 1996.

Meanwhile, the Department has continued one of the main and liveliest microfinance institutions in Palestine and has uniquely developed into a regional operation. In 2003, the section began working in Jordan and Syria, where 2.5 million Palestine immigrants exist in. Between 1991 and 2015, the Section backed 398,154 loans across all grounds of action, at a value of USD 440.41 million. The Figure 2 shows the statistical graph predicting the role of bank loan as an increasing factor towards economic as well institutional development.

Table 3 shows that the role of banks branches out of which 95 are currently dealing with MFIs. With the total of 849 of the staff members associated with them. Furthermore, data about each of a bank branch has been collected from the specific branch head office. 
Table 3. Profile of Banks working in Palestine's (continued ....)

\begin{tabular}{|c|c|c|c|c|c|c|c|c|}
\hline & \multicolumn{2}{|l|}{ UNRWA } & \multicolumn{2}{|l|}{ REEF } & \multicolumn{2}{|c|}{ AL-IBDAA } & \multicolumn{2}{|c|}{ PDF } \\
\hline No. of branches & 11 & & 11 & & 5 & & 6 & \\
\hline No. of staff & 176 & $100 \%$ & 48 & $100 \%$ & 88 & $100 \%$ & 25 & $100 \%$ \\
\hline Male & 109 & $61.93 \%$ & 35 & $72.92 \%$ & 42 & $47.73 \%$ & 14 & $56.00 \%$ \\
\hline Female & 67 & $38.07 \%$ & 13 & $27.08 \%$ & 46 & $52.27 \%$ & 11 & $44.00 \%$ \\
\hline No. of Loan Officers & 75 & $100 \%$ & 22 & $100 \%$ & 45 & $100 \%$ & 8 & $100 \%$ \\
\hline Male & 42 & $56.00 \%$ & 19 & $86.36 \%$ & 19 & $42.22 \%$ & 7 & $87.50 \%$ \\
\hline Female & 33 & $44.00 \%$ & 3 & $13.64 \%$ & 26 & $57.78 \%$ & 1 & $12.50 \%$ \\
\hline No. of active clients & 17,358 & $100 \%$ & 3,182 & $100 \%$ & 8,930 & $100 \%$ & 821 & $100 \%$ \\
\hline Male & 10,695 & $61.61 \%$ & 2,567 & $80.67 \%$ & 4,794 & $53.68 \%$ & 702 & $85.51 \%$ \\
\hline Female & 6,663 & $38.39 \%$ & 615 & $19.33 \%$ & 4136 & $46.32 \%$ & 119 & $14.49 \%$ \\
\hline No. of active clients & 17,358 & $100 \%$ & 3,182 & $100 \%$ & 8,930 & $100 \%$ & 821 & $100 \%$ \\
\hline West Bank & 12,924 & $74.46 \%$ & 1,640 & $51.54 \%$ & 8930 & $100 \%$ & 552 & $67.24 \%$ \\
\hline Gaza & 4,434 & $25.54 \%$ & 1,542 & $48.46 \%$ & 0 & $0.00 \%$ & 269 & $32.76 \%$ \\
\hline
\end{tabular}

Table 4. Profile of Banks working in Palestine

\begin{tabular}{cllllllll}
\hline & ASALA & \multicolumn{3}{c}{ VITAS } & \multicolumn{3}{c}{ ACAD } & \multicolumn{3}{l}{ FATEN } \\
\hline No. of branches & 7 & & 10 & & 7 & 38 & \\
\hline No. of staff & 57 & $100 \%$ & 110 & $100 \%$ & 55 & $100 \%$ & 290 & $100 \%$ \\
\hline Male & 13 & $22.81 \%$ & 66 & $60.00 \%$ & 27 & $49.09 \%$ & 173 & $59.66 \%$ \\
Female & 44 & $77.19 \%$ & 44 & $40.00 \%$ & 28 & $50.91 \%$ & 117 & $40.34 \%$ \\
\hline No. of Loan Officers & 23 & $100 \%$ & 44 & $100 \%$ & 29 & $100 \%$ & 138 & $100 \%$ \\
\hline Male & 8 & $34.78 \%$ & 26 & $59.09 \%$ & 17 & $58.62 \%$ & 89 & $64.49 \%$ \\
Female & 15 & $65.22 \%$ & 18 & $40.91 \%$ & 12 & $41.38 \%$ & 49 & $35.51 \%$ \\
\hline No. of active clients & 4996 & $100 \%$ & 8683 & $100 \%$ & 4843 & $100 \%$ & 41,478 & $100 \%$ \\
\hline Male & 390 & $7.81 \%$ & 6753 & $77.77 \%$ & 2344 & $48.40 \%$ & 28,127 & $67.81 \%$ \\
Female & 4606 & $92.19 \%$ & 1930 & $22.23 \%$ & 2499 & $51.60 \%$ & 13,351 & $32.19 \%$ \\
\hline No. of active clients & 4996 & $100 \%$ & 8683 & $100 \%$ & 4843 & $100 \%$ & 41,478 & $100 \%$ \\
\hline West Bank & 3625 & $72.56 \%$ & 5179 & $59.65 \%$ & 4425 & $91.37 \%$ & 25,652 & $61.84 \%$ \\
Gaza & 1371 & $27.44 \%$ & 3504 & $40.35 \%$ & 418 & $8.63 \%$ & 15,826 & $38.16 \%$ \\
\hline
\end{tabular}

6.1 Microfinance in Palestine an Overview through Secondary Findings

The demand for micro-loans has been up scaled steeply in the West Bank and Gaza Strip in recent years, according to data from the Palestinian Network for Small and Microfinance (Sharakeh), which currently represents 8 microfinance institutions whose total loan portfolio as on March 31, 2017, reached \$234 million a staggering 212\% increase over the $\$ 75$ million portfolios reported by the end of 2011 and between 2007 - 2017, the number of active micro-loans in the West Bank and Gaza Strip rose from 43,131 to 90,353 a whopping 110\% increase. This increase in the number of transactions and amount exceeded all expectations, and the MFIs are gaining more respect and confidence in the trend and products they are offering. This trend is likely to continue, said Sharakeh, predicting that by the end of 2017 the number of loans will exceed the 100,000 mark.

The number of active clients receiving loans from microfinance institutions has grown by an average of $27 \%$ annually since 2007, he added."Microfinance is on the rise in Palestine because it serves small businesses which are growing in number and importance". The Palestinian economy is characterized by the dominance of the small business sector. According to an unofficial study, $92 \%$ of all employment in Palestine is, directly and indirectly, related to small businesses.

Table 5. Number and Value of Microloans

\begin{tabular}{llll}
\hline & Portfolio Amount & \# of active loans & Average size of loan \\
\hline $\mathbf{2 0 0 7}$ & $\$ 75,000,000$ & 43,000 & $\$ 1,744$ \\
\hline $\mathbf{2 0 1 7}$ & $\$ 234,000,000$ & 90,000 & $\$ 2,600$ \\
\hline
\end{tabular}

The above Table 5 represents the lending portfolio, the number of active loans and the average size of loans during the previous ten years 2007-2017. Also, shows that there has been significant progress, especially in the size of the portfolio and the number of loans granted with a mean value $26000 \$$. 


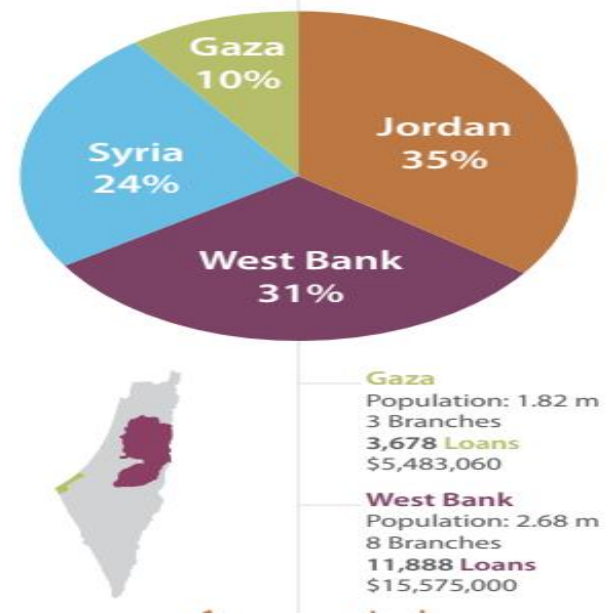

Figure 2. Banks condition in microfinance till 2015

Source: UNRWA Annual Reports 2016

The HQ of the Microfinance Department is founded in Jerusalem; its management runs four ground workplaces in the Jordan, Gaza Strip, the West Bank, and Syria. By way of the culmination of 2015, these field offices were accountable for a whole of 22 branch workplaces. Separately branch is accomplished as an independent cost focus that is compulsory to shelter its direct costs and to fund the complete overhead costs of the program. The creation of new twigs is funded from incomes and reserved earnings, and irregularly by project funds version for the program self-sufficient.

The Subdivision supposes to work with the similar sum of division offices in 2016.In spite of the highly literate population, the Palestinian economy comprises $0.01 \%$ of world economy, and the Unemployment is dangerously high at $26.9 \%$. The Palestinian economy is dependent mainly on government spending \& Services, while the exports are minimal while the economy imports everything from abroad, thus, the growth is weak. Therefore, as it relates to Microfinance, the current state of the economy will be greatly enhanced by increasing investments in productive assets; i.e., industries, agriculture, tourism, IT.

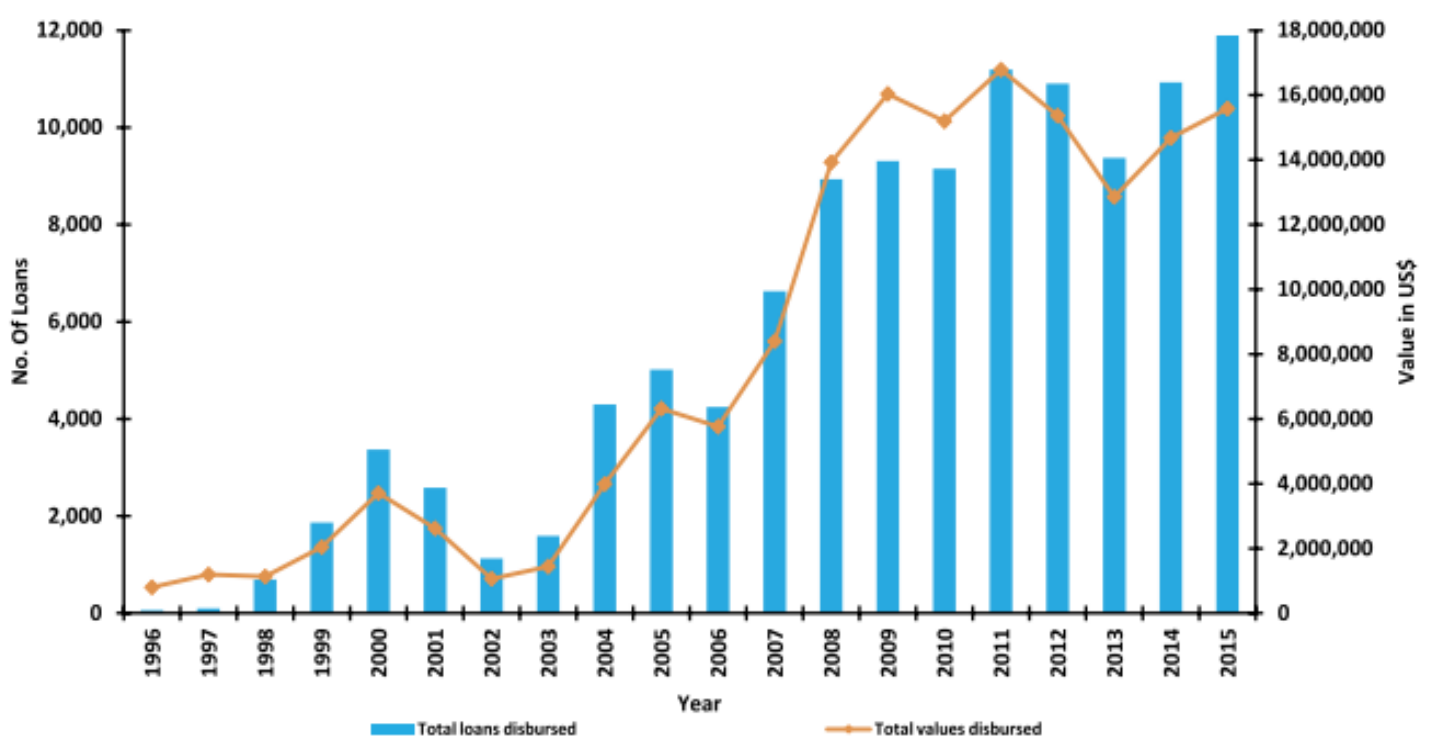

Figure 3. Annual outreach by west Bank till 2015

Source: UNWRA reports 2015

Palestine's penetration of microcredit to the total population stands at $2 \%$ (90K clients of 4.5 million population).To reach the $7.5 \%-10 \%$ penetration mark in Palestine indicates a market size of an additional $240,000-360,000$ microfinance borrowers. The average US\$ loan utilization as on March 31, 2017, amounted to US $\$ 2,591$. Therefore, if we add the 240,000 currently un-served customers, $330,000-90,000$ ) this will create 
an additional demand of around US\$635 Million. Instead of the increasing trend of violence at the beginning of the 2015 in west banks, the department was stable in case of its operations, and the targets were also achieved by the department as they are planned.

The above statistical results show the progress of the micro-financing schemes that are offered by West Bank. Also, it depicts that MFIs role is appreciable for the needy improvement conditions as well as for the institute's development of banks. The program delivered 11,888 loans appreciated at US $\$ 15.58$ million, detecting the development of 8.8 percent in loan facts and 6.2 percent in loan value over 2014. The SPM data displays an upgrading crosswise all social groups over 2014 by a normal growth rate of 11.40 percent. Request for microcredit schemes, intended for debtors who classically lack security, steady employment, and provable credit history has spread by word of mouth, supposed Alaa Abu Halawa, program manager at Sharakeh, count: "The people understood the advantage of MFIs. And its mounting position is appealing more depositors or investors."

Table 6. Women development through MFIs

\begin{tabular}{lllllllll}
\hline Women Clients Data & \multicolumn{2}{c}{ ASALA } & \multicolumn{2}{c}{ VITAS } & \multicolumn{2}{c}{ ACAD } & \multicolumn{1}{c}{ FATEN } \\
No. Of clients - Women & $\mathbf{4 6 0 6}$ & $\mathbf{1 0 0 \%}$ & $\mathbf{1 9 3 0}$ & $\mathbf{1 0 0 \%}$ & $\mathbf{2 4 9 9}$ & $\mathbf{1 0 0 \%}$ & $\mathbf{1 3 , 3 5 1}$ & $\mathbf{1 0 0 \%}$ \\
No. Of West bank women clients & 3235 & $70.23 \%$ & 1025 & $53.11 \%$ & 2311 & $92.48 \%$ & 9,244 & $69.24 \%$ \\
No. Of GAZA women clients & 1371 & $29.77 \%$ & 905 & $46.89 \%$ & 188 & $7.52 \%$ & 4,107 & $30.76 \%$ \\
Women Clients Data & \multicolumn{2}{c}{ UNRWA } & \multicolumn{2}{c}{ REEF } & AL-IBDAA & PDF \\
No. Of clients - Women & 6,663 & $100 \%$ & 615 & $100 \%$ & 4,136 & $100 \%$ & 119 & $100 \%$ \\
West Bank women Clint & 4,913 & $73.74 \%$ & 428 & $69.9 \%$ & 4,136 & $100 \%$ & 83 & $69.75 \%$ \\
No. Of GAZA women clients & 1,750 & $26.26 \%$ & 187 & $30.41 \%$ & 0 & $0.00 \%$ & 36 & $30.25 \%$ \\
\hline
\end{tabular}

Source; Economic Survey Reports

Table 6 from the secondary source data also provide insights that each bank is contributing towards the women empowerment as well enhancing their performance growth by expanding the number of opportunities for women in Palestine's. Role of microfinance in the development of the economy as a women empowerment is also appreciate able. Nisreen Swelem the president of the West Bank at Palestinian stated that (ASALA) that is currently offering the micro-loans towards the advancement of women empowerment microloans with the intentions of to expand this quantity by the number of women's. Many of the training women are now becoming trainers of others as they are paying back to their economy with strong intentions of development of themselves as well the state. The role of Gaza women's Clint as well as west bank Clint's is increasing day by day as the financial institute are supporting them to become the part of production labor of the economy.

\section{Discussion and Conclusion}

It is investigated that MFIs plays the major role and positively contributing toward the economy by direct and indirect means. The more emergent side of these types of financial resources is enhancing women empowerment in the state and a spreading as an emerging trend in developing states. A few decades ago, In Palestine women were not considered as a part of social and economic development perspective but the era has changed the conception paradigmatically is by providing more targeting opportunities for their social and economic welfare.

Banking institutes are playing a very positive and productive role for the direct and indirect benefits associated with the development of the economy. With the concern of the direct benefits majority highlighted that they enhance their growth income as well opportunities especially in livestock's, agriculture, clothing, etc. by the availability of small level financing opportunities.

The results are the consequence of a very specific combination of elements: random shocks affecting the macroeconomic environment; the impossibility of MCIs to raise their own financial resources; and very strong political and ideological aims behind the support of international donors. Thus it would be a mistake to try to generalize the 'lessons' of the Palestinian experience. However, some of the aspects analyzed in this article, for example the problematic interaction between donors and managers, are common to various experiences over time and space and they offer some more general insights on the functioning of the microcredit industry.

Furthermore, the secondary data reports, archives explored that the bank's performance in the ends of clients, staff performances, prevailing branches' scope as well as economic stability figure margin differences are linked with the indirect benefits associated with the MFIs.

The current study concludes that the small level microfinancing is the best resource for the economic stability as well development. This, not just impacts on the poverty in the sense of the food and clothing but also enhance the employments opportunities that are also linked to the financial stability of the state. 


\section{References}

Barr, M. (2005) Microfinance and Financial Development. Michigan Journal of International Law, 26, 271.

Bateman, M. (2012, May). Let's not kid ourselves that financial inclusion will help the poor. Retrieved from The Guardian-Global Development - Poverty Matters: http://www.theguardian.com/global-development/povertymatters/2012/may/08/financial-inclusion-poor-mic rofinance

Cull, R., Asli, D. K., \& Jonathan, M. (2017). “The Microfinance Business Model: Enduring Subsidy and Modest Profit.” World Bank Policy Research Working Paper 7786.

Ha-Joon, C. M. (2012). "Microfinance and the Illusion of Development: From Hubris to Nemesis in Thirty Years." World Economic Review, 1, 13-36.

Honohan, P. (2004) Financial Sector Policy and the Poor: Selected Findings and Issues. World Bank Working Paper No. 43, Washintong D.C.

Hulme, D., \& Mathilde, M. (2014). "Has Microfinance Lost Its Moral Compass?" Economic and Political Weekly, 49(48), November: 77-85. https://doi.org/10.2139/ssrn.2560331

Kai, H., \& Hamori, S. (2009). Micronance and Inequality. MPRA Paper No. 17572, September 2009.

Karim, L. (2011). Microfinance and Its Discontents: Women in Debt in Bangladesh. Minneapolis, MN: University of Minnesota Press. https://doi.org/10.5749/minnesota/9780816670949.001.0001

Mossman. M. (2015). "Moving Beyond Microcredit.” The New Yorker. November 2, 2015.

Nagarajan, G., \& McNulty, M. (2004). Microfinance amid conflict: Taking stock of available literature; Accelerated microenterprise advancement project. Washington, USAID.

Ravallion, M. (2001) Growth, Inequality, and Poverty: Looking beyond Averages. World Development, 29(11), 23-49. https://doi.org/10.1596/1813-9450-2558

Sabri, N. (1999). General features of Palestinian Industry. International management, 3, 33-42. Available online at http://home.birzeit.edu/commerce/sabri/man.pdf

Sabri, N. R. (2008). Small businesses and entrepreneurs in Palestine. Working Paper Series. Birzeit: Birzeit University.

Schicks, J. (2013). "The Definition and Causes of Microfinance Over-Indebtedness: A Customer Protection Point of View." Oxford Development Studies, 41, S95-S116. https://doi.org/10.1080/13600818.2013.778237

UNWRA Economic review https://www.unrwa.org/annual_report_2015.pdf

\section{Copyrights}

Copyright for this article is retained by the author(s), with first publication rights granted to the journal.

This is an open-access article distributed under the terms and conditions of the Creative Commons Attribution license (http://creativecommons.org/licenses/by/4.0/). 